\title{
Validation of HPLC-UV Patulin Determination Method in Traditional Juices From Côte d'Ivoire
}

\author{
Kpan Kpan Kouakou Gains, \\ Laboratoire National d'Appui au Développement Agricole (LANADA), \\ Laboratoire Central (LCAE), Côte d'Ivoire \\ Kouacou Kouassi William Dominique, \\ UFR Sciences des Structures de la Matière et de la Technologie, \\ Université Félix Houphouët, Côte d'Ivoire \\ Kouakou Konan Jean-Marie, \\ Yao Brou Lazare, \\ Laboratoire National d'Appui au Développement Agricole (LANADA), \\ Laboratoire Central (LCAE), Côte d'Ivoire \\ Trokourey Albert, \\ UFR Sciences des Structures de la Matière et de la Technologie, \\ Université Félix Houphouët, Côte d'Ivoire \\ Dembele Ardjouma, \\ Laboratoire National d'Appui au Développement Agricole (LANADA), \\ Laboratoire Central (LCAE), Côte d'Ivoire
}

Doi:10.19044/esj.2019.v15n36p253 URL:http://dx.doi.org/10.19044/esj.2019.v15n36p253

Abstract

Object: The need to reduce dietary mycotoxins exposure, requires development of efficient analytical methods to assess mycotoxins level in food. The purpose of this study was to validate HPLC-UV method for patulin determination in traditional juices made of dry Guinea sorrel flowers or ginger rhizomes. Material and Methods: Patulin was extracted with ethyl acetate and purified with sodium bicarbonate solution (14 g/L). Elution of patulin was realised in isocratic mode with mobile phase consisting of acetonitrile-water (10/90 : v/v). Patulin was detected at $276 \mathrm{~nm}$ (UV). An amount of patulin was added to neutral portions of juices and the recovery rates were estimated after extraction. Results: The retention time was $5.03 \mathrm{~min}$ and the coefficient of determination of the calibration range $(100-1500 \mu \mathrm{g} / \mathrm{L})$ was 0.9994 . Detection and quantification limits were respectively $1.4 \mu \mathrm{g} / \mathrm{L}$ and $4.6 \mu \mathrm{g} / \mathrm{L}$ for the two matrices. The recovery rates were $75.09 \pm 0.27 \%$ and $75.27 \pm$ $0.64 \%$ respectively for ginger and Guinea sorrel juices. Patulin was detected in $55 \%$ of ginger juice and $70 \%$ of Guinea sorrel juice. Patulin contents of 
$15 \%$ of ginger juice and $40 \%$ of Guinea sorrel juice were above the maximum level of patulin $(50 \mu \mathrm{g} / \mathrm{L})$ allowed in juices. Conclusion: This method may be used for patulin detection in these traditional juices because its recovery rates were acceptable and limit of quantification $(4.6 \mu \mathrm{g} / \mathrm{L})$ was largely bellow the maximum level of patulin $(50 \mu \mathrm{g} / \mathrm{L})$ allowed in juices.

Keywords: HPLC, Patulin, Hisbiscus Sabdariffa, Zingiber Officinale

\section{Introduction}

Mycotoxins are secondary metabolites produced by toxigenic strains of several mould species belonging to Aspergillus, Penicillium, Fusarium, Byssochlamys, Alternaria genera. Even at low levels of micrograms per litre or per kilogram (ppb), these substances may be harmful to humans and animals. Their toxicity is expected on vital organs such as liver, kidneys, lungs and immune system. They are also able to reduce human performance by affecting growth, and disrupting the animal's reproduction (ChapelandLeclerc et al., 2005; Galtier et al., 2006; AFSSA, 2006).

Unfortunately, toxigenic fungi exist in nature and can contaminate food and food products (Huybrechts et al., 2013). The presence of these fungi in food may lead to the contamination of primary foodstuffs and their derived products with mycotoxins. According to the Food and Agriculture Organization (FAO), about $25 \%$ of crops are contaminated with mycotoxins (FAO, 2004).

Among these mycotoxins, patulin (4-hydroxy-4H-furo [3,2-c] pyran$2(6 \mathrm{H})$ one) is problematic for fruit juice, as this mycotoxin is frequently found in fruit products, and particulary in apple juice. It is synthesized by several mouldy species belonging to Penicillium, Aspergillus, Byssochlamys genera. But these mycotoxin is mainly produced by Penicillium expansum (Shephard and Leggott, 2000). The British Committee for the Mutagenicity of Chemicals in Food, Consumables and the Environment has classified patulin as mutagenic agent (United Kingdom Committee on Toxicity, Mutagenicity and Carcinogenicity of Chemicals in Food, Consumer Products and the Environment, 1992). The Joint FAO/WHO Expert Committee on Food Additives (JECFA) admitted, that patulin can cause embryotoxicity with toxicity to surrogate mother. Studies have also concluded that patulin is genotoxic even if its carcinogenicity has not been demonstrated (FAO, 1995). In West Africa and particularly in Côte d'Ivoire, "Bissap", a traditional juice made of dry Guinea sorrel flowers (Hisbiscus sabdariffa) and "Gnamankou", another traditional juice made of ginger (Zingiber officinale) rhizomes, are very well appreciated during celebrations (wedding, baptism, birthday etc.) and ordinary meals. In view the high consumption of these juices and the need of precautionary principle application, these drinks must carefully be 
examined to secure consumers. Otherwise, these juices must be subject to strict regulation in relation to their mycotoxins content, and particularly patulin which is major mycotoxin found in juices.

Achieving level of patulin in Guinea sorrel and ginger juices requires efficient analytical methods able to detect lower amounts of patulin in these juices. Previous analytical methods were elaborated for patulin detection in apple juice and its derivatised products (Herry and Lemetayer, 1996; Brause et al.,1996 ; Shephard and Leggott, 2000 ; Matthew et al., 2005), and have not yet been sufficiently tested on traditional juices made of Guinea sorrel and ginger. That situation constitutes a loss of income, or even a challenge to be taken up in order to contribute to the valorisation of traditional juice made of H. sabdariffa and Z. officinale juices.

Thus, the purpose of this study was to apply the high performance liquid chromatographic method (HPLC-UV), initially intended for patulin determination in apple juice, to Guinea sorrel and ginger juices to evaluate the effectiveness of this method on these matrices.

\section{Material and methods}

\section{Solvents and reagents}

The solvents and reagents used were acetic acid (100\%) NORMAPHUR (Leuven, Belgium), sodium acetate $(99.5 \%)$ SCHARLAU (Sentmenat, Spain), sodium carbonate (99.7\%) MERCK (Darmstadt, Germany), acetonitrile HPLC CHEM-LAB (Zedelgem, Belgium), sodium sulphate anhydrous (99.2\%) ANALAR NORMAPHUR (Leuven, Belgium). Ultra pure water was obtained using ELGA device (High Wycombe, England).

\section{Apparatus}

A SHIMADZU HPLC system (Tokyo, Japan) equipped with DGU20A5 degasser, LC-20AT pump, SIL-20A automatic sampler, TRAY tank, CTO-20A oven and SPD-20A UV/VIS detector, was used to detect patulin. An analytical balance SHIMADZU (Tokyo, Japan) and a rotary evaporator BUCHI (Switzerland) were respectively used for weighing reagents and evaporating undesirable solvents. To measure and adjust the $\mathrm{pH}$ of the prepared solutions, NAHITA $\mathrm{pH}$ meter (Beriain, Spain) was used. The prepared solutions were homogenized by means of NAHITA agitator (Beriain, Spain).

\section{Calibration standards}

The standard for 4-Hydroxy-4H-furo [3,2-c] pyran-2(6H)-one (patulin) ( $\geq 98.0 \%$ ) was provided by TRILOGY (Washington, USA). The initial concentration of the standard was $25.2 \pm 1.96 \mu \mathrm{g} / \mathrm{mL}$ in acetonitrile. 


\section{Samples collecting}

Two types of juice were analysed, namely Bissap, juice obtained by infusing the dry flowers of Guinea sorrel, and "Gnamankou" extracted from crushed ginger rhizomes. The juice samples were collected in sales outlets located in the commune of Treichville (Abidjan). The volume of each sample was $500 \mathrm{~mL}$. These samples were stored at $-4^{\circ} \mathrm{C}$ before analysis.

\section{Preparation of solutions}

The buffer solution ( $\mathrm{pH}=4$ ) used for dissolving patulin residues was consisted of $16.4 \mathrm{~mL}$ of acetic acid solution $(0.2 \mathrm{~mol} / \mathrm{L})$ and $3.6 \mathrm{~mL}$ of sodium acetate solution $(0.2 \mathrm{~mol} / \mathrm{L})$. Acetonitrile content of patulin standard $(330 \mu \mathrm{L})$ was totally evaporated and patulin was recovered with $2500 \mu \mathrm{L}$ of the buffer solution. The final solution obtained was stored at $5^{\circ} \mathrm{C}$. The sodium carbonate solution $(14 \mathrm{~g} / \mathrm{L})$ for patulin extraction, was obtained dissolving $1.4 \mathrm{~g}$ of sodium carbonate into $100 \mathrm{~mL}$ of ultrapure water.

\section{Liquid - Liquid Extraction (LLE) of Patulin}

The method used to determine patulin is based on ISO 8128 (ISO, 1993) and modified to be adapted to laboratory conditions. This ISO method is specific to apple juice, concentrated apple juice, and other beverages containing apple juice.

A volume of $5 \mathrm{~mL}$ of juice was extracted with 3 successive portions of $5 \mathrm{~mL}$ ethyl acetate for 1 minute by heavy agitation using vortex shaker. The combined organic phases were extracted with $2 \mathrm{~mL}$ aqueous sodium carbonate solution $(1.4 \mathrm{~g} / 100 \mathrm{~mL})$ using separating funnel. The aqueous phase was separated and immediately extracted with $5 \mathrm{~mL}$ of ethyl acetate after one minute homogenization.

The combined organic phases were dried with $2 \mathrm{~g}$ of sodium sulphate anhydrous and filtered on Whatman filter $\mathrm{N}^{\circ} 4$. Then 5 drops of acetic acid were added to neutralize sodium carbonate. The extract was evaporated at $40^{\circ} \mathrm{C}$ using a rotary evaporator. The residue was dissolved in $500 \mu \mathrm{L}$ of the buffer solution $(\mathrm{pH}=4)$. The sample was filtered through PTFE disc filter with $0.45 \mu \mathrm{m}$ porosity and the final solution was collected in a vial and injected into the chromatographic system.

\section{Instrumental analysis}

The detection of patulin in fruit juices and standard solutions was realised using HPLC system quipped with LICHROSORB 100 RP-18 column ( $5 \mu \mathrm{m}, 250 \times 4 \mathrm{~mm}$ ID). Elution was carried out in isocratic mode using mobile phase consisting of acetonitrile/water $(10: 90 ; \mathrm{v} / \mathrm{v})$ with a flow rate of 1 $\mathrm{mL} / \mathrm{min}$. The oven temperature and wave length were respectively set at $40^{\circ} \mathrm{C}$ 
and $276 \mathrm{~nm}$ (Brause et al., 1996). Injection volume was $20 \mu \mathrm{L}$ and the analysis took $10 \mathrm{~min}$.

\section{Specificity}

Specificity of the method was established using different dilutions (100, 250 and $500 \mu \mathrm{g} / \mathrm{L})$ of palutin standard. These solutions were injected into the HPLC in ascending order, and the standard dilution solution was injected into the HPLC under the same conditions as the standard solutions. The comparison of different chromatograms led to identify patulin pic and its retention time.

\section{Linearity}

Linearity was determined using five (06) dilutions $(0 ; 100 ; 250 ; 250$ ; 500; $500 ; 1000$ and $1500 \mu \mathrm{g} / \mathrm{L})$ of patulin standard solution in sodium acetate buffer. These solutions were injected in ascending order into the HPLC system. The simple linear regression test was performed on the concentrations of the standard solutions and the associated peak areas, to assess the relationship between the peak areas and the patulin content of the standard solutions. This test was performed using XLSAT PRO 7.5 software.

\section{Accuracy}

This analytical parameter was evidenced by the recovery rate (RT) which is the percentage of the difference between the patulin content (after extraction) of a fortified portion of juice sample and the patulin content of another unfortified portion of the same juice sample. Portions of Bissap and Gnamankou were fortified with patulin standard to obtain $50 ; 100$ and 150 $\mu \mathrm{g} / \mathrm{L}$ of patulin. Then, patulin was extracted from $5 \mathrm{~mL}$ of each fortified juice portion, after a rest period. The same extraction method was applied to $5 \mathrm{~mL}$ of each type of unfortified juice. The recovery rate was expressed as follows:

\section{$\mathbf{R T}(\boldsymbol{\%})=\left(\mathbf{C}_{\mathbf{f}}-\mathbf{C}\right) / \mathbf{C a} \times \mathbf{1 0 0}(\mathrm{CEAEQ}, 2015)$}

Where

$\mathrm{RT}$ : recovery rate $(\%)$;

$\mathrm{C}_{\mathrm{f}}$ : patulin of content of the fortified juice portion $(\mu \mathrm{g} / \mathrm{L})$;

C : patulin content of the unfortified juice portion $(\mu \mathrm{g} / \mathrm{L})$;

$\mathrm{Ca}$ : estimated patulin content of the fortified juice portion $(\mu \mathrm{g} / \mathrm{L})$.

The patulin contents of the juices were determined using following formula:

$\mathrm{C}=\left(\mathbf{C}_{\mathbf{0}} \times \mathbf{V}_{\mathbf{f}} \times \mathbf{F}\right) /\left(\mathbf{V}_{\mathbf{j}} \times \mathbf{R T}\right)$

Where

C : patulin content of juice $(\mu \mathrm{g} / \mathrm{L})$;

$\mathrm{C}_{0}$ : patulin content obtained from the calibration curve $(\mu \mathrm{g} / \mathrm{L})$; 
F : dilution Factor

$V_{f}$ : final volume of the extract $(\mathrm{mL})$;

$\mathrm{Vj}$ : volume of juice used for extraction $(\mathrm{mL})$;

RT : Recovery Rate (\%).

\section{Fidelity}

Accuracy was assessed through repeatability which was obtained through ten successive injections of solutions of $100 \mu \mathrm{g} / \mathrm{L}$ and $250 \mu \mathrm{g} / \mathrm{L}$ patulin, which belong to the calibration range. Repeatability was also applied to a Gnamankou sample. The coefficients of variation were determined with the following formula:

$\operatorname{RSD}(\%)=100 \boldsymbol{\sigma}_{(\mathrm{n}-\mathbf{1})} / \overline{\boldsymbol{x}}$ (Feinberg, 1995)

RSD : relative standard deviation;

$\sigma_{(\mathrm{n}-1)}:$ standard deviation ;

$\bar{x} \quad$ : Average.

\section{Sensitivity}

The solution with the lowest patulin content $(100 \mu \mathrm{g} / \mathrm{L})$ in the calibration range was injected 10 times in into the chromatographic system and then the standard deviation $\left(\sigma_{\mathrm{n}-1}\right)$ was determined. The detection limit (LOD) was assimilated to $3 \sigma_{\mathrm{n}-1}$ when the limit of quantification was $10 \sigma_{\mathrm{n}-1}$ (Institut National de Santé Publique du Québec, 2013).

\section{Results and discussion}

\section{Results}

\section{Specificity}

On the chromatograms of patulin standard solutions $(100 ; 250 ; 500$ $\mu \mathrm{g} / \mathrm{L}$ ) and juices the peak of patulin was distinguished. This peak appeared at $5.03 \pm 0.02 \mathrm{~min}$ (Figue 1-4).

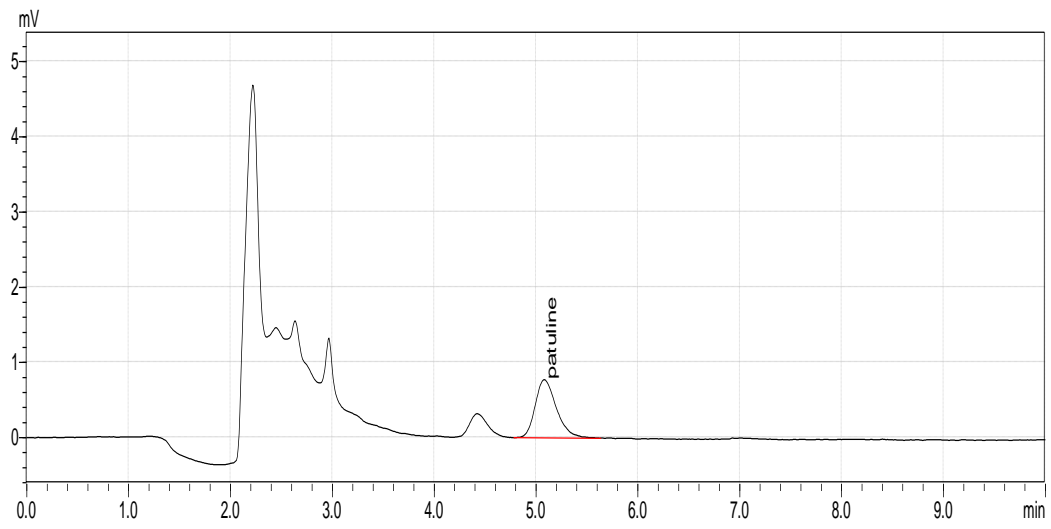

Figure 1: Chromatogram of patulin standard $(100 \mu \mathrm{g} / \mathrm{L})$ 


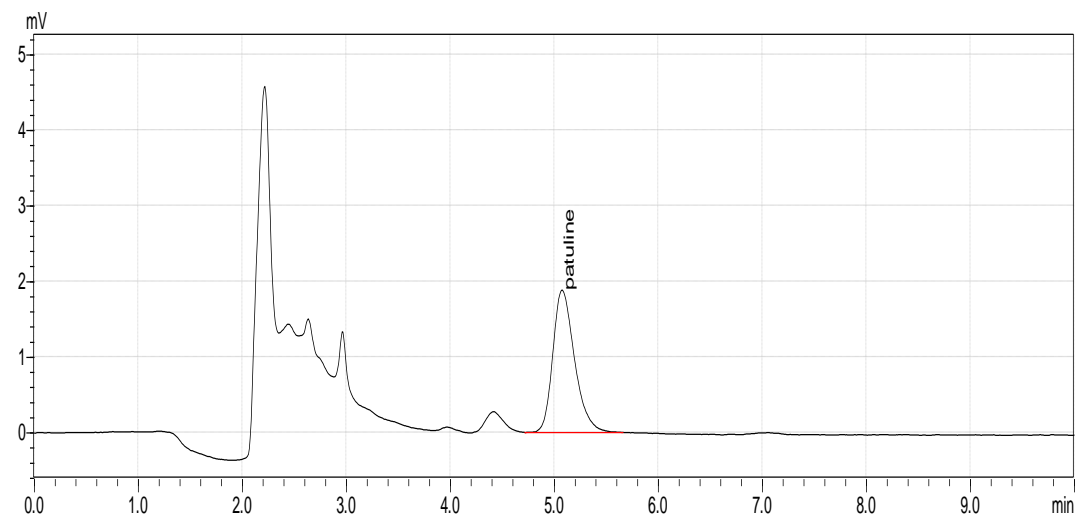

Figure 2: Chromatogram of patulin standard $(250 \mu \mathrm{g} / \mathrm{L})$

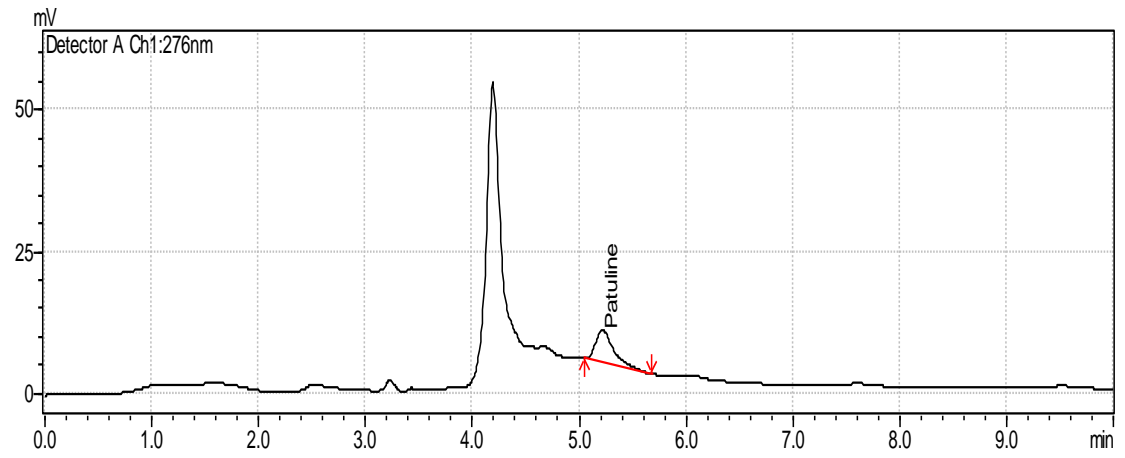

Figure 3: Chromatogram of Bissap extrac

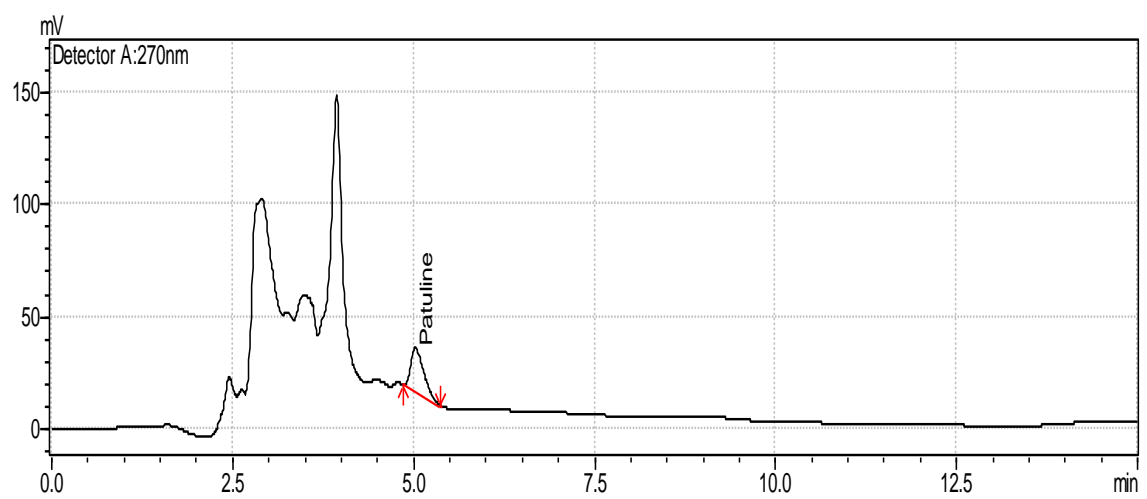

Figure 4 : Chromatogram of Gnamankou extract

\section{Linearity}

The coefficient of determination $\left(\mathrm{R}^{2}\right)$ of the linear regression was 0.9994 . The value of probability associated with the Fisher F test was less than $5 \%(\mathrm{p}=0.001)($ Table 1$)$. 
Table 1: Evaluating the information brought by the variables

\begin{tabular}{cccccc}
\hline Source & $\begin{array}{c}\text { Degree of } \\
\text { Freedom }\end{array}$ & $\begin{array}{c}\text { Sum of } \\
\text { squares }\end{array}$ & $\begin{array}{c}\text { Mean } \\
\text { square }\end{array}$ & Fisher's F & Pr $>$ F \\
\hline Model & 1 & 19450.809 & 19450.809 & 6300.358 & $<0.0001$ \\
Residuals & 4 & 12.349 & 3.087 & & \\
Total & 5 & 19463.158 & & & \\
\hline
\end{tabular}

The equation of the model was $\mathrm{Y}=0.1069 \mathrm{X}-0.401$ (Figure 5)

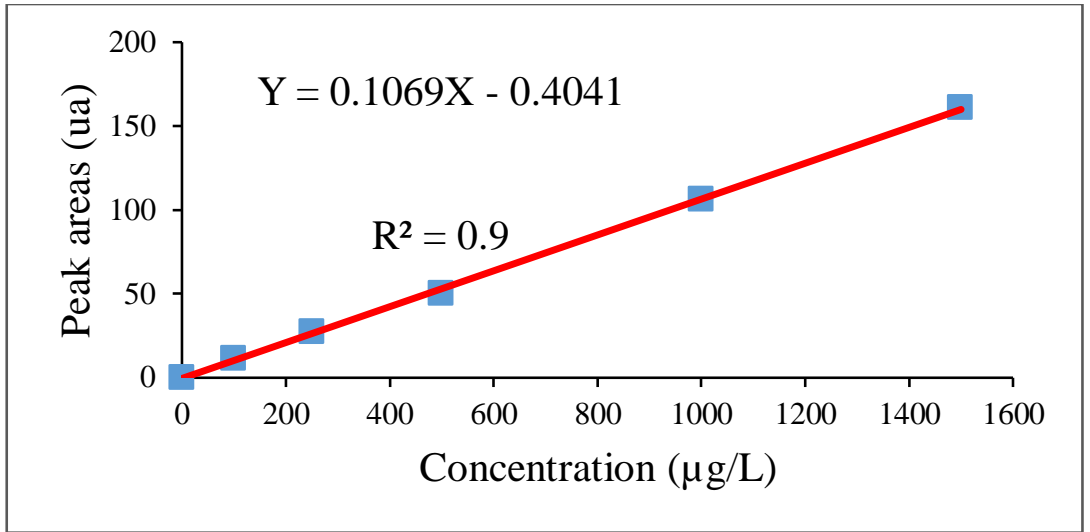

Figure 5: Linear regression line between patulin concentrations and peak areas

\section{Accuracy}

For the Bissap, the recovery rate ranged from $74 \%$ to $76 \%$ with an average of $75.27 \pm 0.64 \%$. The recovery rate varied between 74.67 and 75.59 $\%$ with an average of $75.09 \pm 0.27 \%$ for Gnamankou (Table 2).

Table 2: Recovery rates for Bissap and Gnamankou

\begin{tabular}{lllcc}
\hline Analytical & Type of juice & \multicolumn{4}{l}{ Patulin level in fortified juice $(\mu \mathrm{g} / \mathrm{L})$} & \\
\cline { 3 - 5 } parameter & 50 & 74 & 760 & 750 \\
\hline $\begin{array}{l}\text { Recovery rates } \\
(\%)\end{array}$ & Bissap & 75.8 & 74.67 \\
\hline
\end{tabular}

\section{Fidelity and Sensitivity}

The coefficients of variation were $0.4 \%$ and $1.91 \%$ respectively for $100 \mu \mathrm{g} / \mathrm{L}$ and $250 \mu \mathrm{g} / \mathrm{L}$ of patulin standard. For the juice (Gnamankou), the coefficient of variation was $3 \%$ (Table 3 ). 
Table 3: Repeatability parameters for patulin standards

\begin{tabular}{|c|c|c|c|c|c|}
\hline $\begin{array}{l}\text { Patulin } \\
\text { standard }\end{array}$ & $\begin{array}{c}\text { Injection } \\
\text { number }\end{array}$ & $\begin{array}{l}\text { Peak area } \\
\text { (ua) }\end{array}$ & $\begin{array}{c}\text { Mean } \\
\text { peak } \\
\text { area }\end{array}$ & $\begin{array}{l}\text { Standard } \\
\text { deviation }\end{array}$ & RSD (\%) \\
\hline \multirow{10}{*}{$100 \mu \mathrm{g} / \mathrm{L}$} & 1 & 10.489 & \multirow{10}{*}{10.489} & \multirow{10}{*}{0.049} & \multirow{10}{*}{0.470} \\
\hline & 2 & 10.480 & & & \\
\hline & 3 & 10.492 & & & \\
\hline & 4 & 10.549 & & & \\
\hline & 5 & 10.557 & & & \\
\hline & 6 & 10.449 & & & \\
\hline & 7 & 10.446 & & & \\
\hline & 8 & 10.551 & & & \\
\hline & 9 & 10.474 & & & \\
\hline & 10 & 10.586 & & & \\
\hline \multirow{10}{*}{$250 \mu \mathrm{g} / \mathrm{L}$} & 1 & 26.259 & \multirow{10}{*}{26.259} & \multirow{10}{*}{0.501} & \multirow{10}{*}{1.907} \\
\hline & 2 & 26.193 & & & \\
\hline & 3 & 25.634 & & & \\
\hline & 4 & 26.054 & & & \\
\hline & 5 & 26.158 & & & \\
\hline & 6 & 26.059 & & & \\
\hline & 7 & 25.834 & & & \\
\hline & 8 & 25.944 & & & \\
\hline & 9 & 24.536 & & & \\
\hline & 10 & 25.965 & & & \\
\hline
\end{tabular}

Concerning the sensitivity, the detection limit (LOD) and quantification limit (LOQ) were $1.39 \mu \mathrm{g} / \mathrm{L}$ and $4.63 \mu \mathrm{g} / \mathrm{L}$ respectively (Table 4 ).

Table 4: Sensitivity parameters

\begin{tabular}{cccc}
\hline Injection number & $\begin{array}{c}\text { Concentrations } \\
(\mu \mathrm{g} / \mathrm{L})\end{array}$ & $\mathrm{LOD}(\mu \mathrm{g} / \mathrm{L})$ & LOQ $(\mu \mathrm{g} / \mathrm{L})$ \\
\hline 1 & 98.49432 & & \\
2 & 98.41134 & & \\
3 & 98.52804 & & \\
4 & 99.05872 & & \\
5 & 99.13501 & & \\
6 & 98.12706 & & \\
7 & 98.09813 & & \\
8 & 99.08382 & & \\
9 & 98.35984 & & \\
10 & 99.41346 & & \\
Standard deviation & 0.463 & & \\
\hline
\end{tabular}

\section{Patulin contents of the juices}

Thirty (30) samples of juice (15 samples of each type of juice) were analysed, and patulin was found in $70 \%$ of Bissap samples and in $(55 \%)$ of Gnamankou samples. 
Maximal and minimal contents of patulin was respectively $5.41 \mu \mathrm{g} / \mathrm{L}$ and $68.87 \mu \mathrm{g} / \mathrm{L}$ for Gnamankou, while patulin average content for this juice was $32.82 \mu \mathrm{g} / \mathrm{L}$. Patulin was detected in $55 \%$ of Gnamankou samples, and the contents of $15 \%$ of these samples were above the maximum level of patulin $(50 \mu \mathrm{g} / \mathrm{L})$ allowed in juice by Food and Drug Administration (FDA) (Figure $6)$.

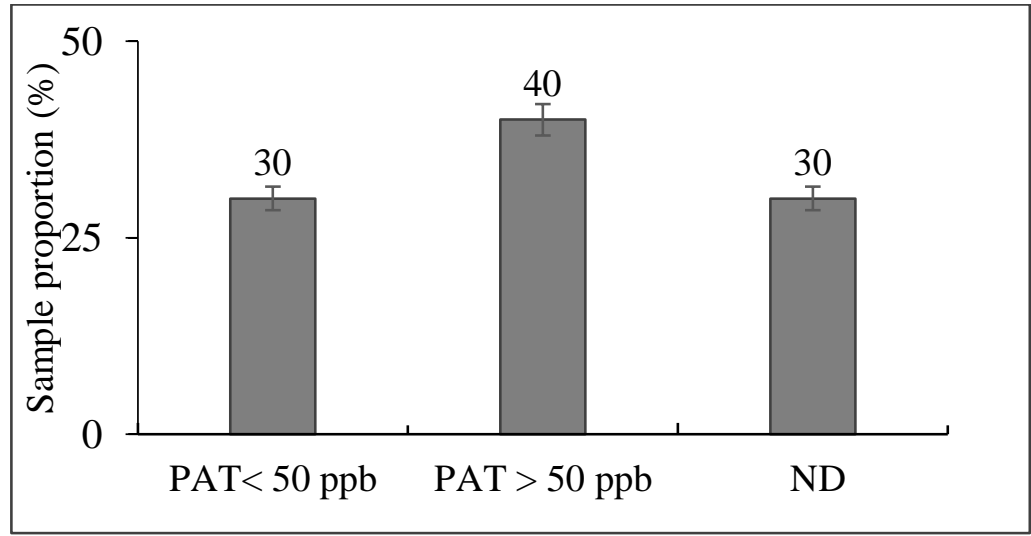

PAT : patulin ; ND : not detected

Figure 7: Comparison of patulin content of Bissap to the maximum level of patulin $(50 \mu \mathrm{g} / \mathrm{L})$ allowed in juice

\section{Discussion}

Patulin retention time of $5.03 \pm 0.02 \mathrm{~min}$ is relatively short. This relative short time can allow several analyses within a short time. That is essential for laboratories involved in food safety, which usually must provide analytical results within short time. This retention time confirms those obtained by Barreira et al. (2010) who detected patulin around 5 min using high performance liquid chromatography.

The linearity of the method is satisfactory because the coefficient of determination $\left(\mathrm{R}^{2}=0.9994\right)>0.98$ which is the guide value for linear regression in chromatographic methods (HPLC) (Blanchin, 2010). The method is linear in the calibration range $(0 ; 100 ; 100 ; 250 ; 500 ; 1000$ and 1500 $\mu \mathrm{g} / \mathrm{L})$.

The average recovery rate of $75.27 \pm 0.64 \%$ for Bissap and $75.09 \pm$ $0.27 \%$ for Gnamankou respect the reference range which is 70 to $130 \%$ according to Blanchin (2010). Consequently, these recovery rates are acceptable. These recovery rates are significantly similar to those obtained by Stray (1978) and Tanner and Zanier (1976) (Shephard and Leggott, 2000). These authors obtained respective recovery rates of $78.4 \pm 7.3 \%$ and $81.4 \pm$ $15 \%$. However, recovery rates of this study are lower than the value (96\%) obtained in the collaborative study between AOAC International, International Union of Pure and Applied Chemistry, and the International Fruit Juice Union 
(Brause et al., 1996). Other studies, including the works of Herry and Lemetayer (1996) on the detection of patulin in apple juices and products derived, led to recovery rates ranging from $90.4-104 \%$.

These differences between the recovery rates of previous studies and the present study may be due to the nature of the juice and extraction protocols. Unlike apple juice, traditional ginger juice is substantially rich in starch, which is visible when the juice is left to sufficiently rest. According to Amani et al (2004), ginger starch contains $0.18 \%$ protein for starch grain sizes between 6.43 and $38.56 \mu \mathrm{m}$. However, some studies suggested that patulin binds to proteins contained in solid residues, and patulin content of the liquid phase decreases over time as the result of the interaction between this mycotoxin and the solid elements of the juices (Brackett and Marth, 1976).

As analytical protocol concerned, insufficient separation of the organic phase from the aqueous phase, loss of patulin during evaporation of extraction solvent and insufficient extraction time may be the reasons of lower value of recovery rate.

Repeatability is satisfactory in so far as the coefficients of variation $(0.47 \%$ and $1.907 \%)$ associated with this study are included the range of repeatability variation coefficient (10-20\%) recommended by Directive 2002/657/EC (EC, 2002).

The detection limit (LOD) $(1.4 \mu \mathrm{g} / \mathrm{L})$ shows high sensitivity of the method. The limit of quantification (LOQ) $(4.6 \mu \mathrm{g} / \mathrm{L})$ is acceptable as this value is largely below the maximum limit of patulin in juices $(50 \mu \mathrm{g} / \mathrm{L})$ (USFDA, 2004). Under the same chromatographic conditions like those of this study, the LOQ of ISO $8128(10 \mu \mathrm{g} / \mathrm{L})$ is almost twice the LOQ of the present study (ISO, 1993). By modifying the composition of the mobile phase (wateracetonitrile (99:1)), and using a stationary phase consisting of C18 Micropak column with a flow rate of $1 \mathrm{~mL} / \mathrm{min}$, Gökmen et Acar (1998) obtained LD < $5 \mu \mathrm{g} / \mathrm{L}$ of palutin for apple juice. Herry and Lemetayer (1996) achieved LOQ of $10 \mu \mathrm{g} / \mathrm{L}$ for patulin in apple wax from France. The variations observed between the LOQ of the present study and those of previous studies may be due to the difference between the matrices. The interference of the matrix components on a specific molecule, generally differs from one matrix to another matrix. In addition, the sensitivity of analytical methods sometimes depends on the operator and the analytical method chosen. Thus, different modes for LOD and LOQ determination remain in the literature (Alankar and Vipin, 201; CEAEQ, 2015; Vassault et al., 2010). These different ways of LOD and LOQ determination affects the value of these parameters.

The proportion of Bissap samples contaminated by patulin $(77 \%)$ is higher than those of Gnamankou samples (55\%). The quantity of Bissap samples $(40 \%)$ which patulin levels were above the norm, was higher than those of Gnamankou (15\%). The presence of patulin in Bissap and 
Gnamankou confirms the results of Aké et al. (2001) who also reported the presence of this mycotoxin in $18 \%$ of the juices marketed in Côte d'Ivoire. This contamination of Gnamankou and Bissap by patulin suggests that the flowers of $H$. sabdariffa and the rhizomes of $G$. officinale must be submitted to Good Agricultural Practices such as drying and post-harvest storage to minimize the presence of moulds in these matrices. The level of patulin must be controlled in traditional juices before marketing.

\section{Conclusion}

The validation parameters measured were satisfactory for the two types of juice. The quality of the linearity was demonstrated by the high determination coefficient $\left(\mathrm{R}^{2}\right)$ of 0.9994 . The average recovery rate of 75.27 $\pm 0.64 \%$ for Bissap and $75.09 \pm 0.27 \%$ for Gnamankou was quite high. The limit of quantification which was $4.6 \mu \mathrm{g} / \mathrm{L}$ is very satisfactory as it is largely below the maximum limit of patulin $(50 \mu \mathrm{g} / \mathrm{L})$ allowed in fruit juices. The quantity of patulin found in the juices $(5.41 \mu \mathrm{g} / \mathrm{L}$ to $716.10 \mu \mathrm{g} / \mathrm{L})$ shows the ability of the method to detected small and large amount of patulin in the traditional juices concerned.

Although today, liquid chromatography coupled with mass spectrometer (LC-MS or LC-MS/MS) is undergoing major development in the determination of mycotoxins, the validation of this patulin determination method for Bissap and Gnamankou, is an asset for laboratories, especially for those who do not have access to LC-MS because of the high cost of this device.

\section{References:}

1. Chapeland-Leclerc, F., Papon, N., Thierry, N., \& Villard, J. (2005). Moisissures et risques alimentaires (mycotoxicoses). Revu Française des Laboratoires ; 2005(373) : 61-66.

2. Galtier, P., Loiseau, N., Oswald I.P., \& Puel, O. (2006). Toxicologie des mycotoxines : dangers et risques en alimentation humaine et animale. Bulletin Académie Vétérinaire France ; 159(1):5-13.

3. AFSSA. 2006. Évaluation des risques liés à la présence de mycotoxines dans les chaînes alimentaires humaine et animale. Rapport synthétique ; 82 p.

4. Huybrechts, B., Tangni, E.K., De bongnie, P., Geys, J., \& Callebaut, A. (2013). Méthodes analytique s de détermination des mycotoxine s dans les produits agricoles : une revue. Cahier Agriculture ; 22(3) : 2022015.

5. FAO. (Food and Agriculture Organization of the United Nations). (2004). Worldwide regulations for mycotoxins in food and feed in 2003. FAO Food and Nutrition paper 81; FAO, Rome, Italy. 
6. Shephard, G.S., Leggott, N.L., (2000). Chromatographic determination of the mycotoxin patulin in fruit and fruit juices. Journal of Chromatography A ; 882 (2000) : 17-22.

7. United Kingdom Committee on Toxicity, Mutagenicity and Carcinogenicity of Chemicals in Food, Consumer Products and the Environment. 1992. Annual Report, HMSO, London.

8. FAO (Food and Agricultural Organization, World Health Organization). (1995). Evaluation of Certain Food Additives and Contaminants. 44th Report of the Joint FAO/WHO Expert Committee on Food Additives, Tech. Report Series, Vol. 859, WHO, Geneva.

9. Herry, M.P., \& Lemetayer, N. (1996). Liquid chromatographic determination of patulin in French apple ciders. Journal of AOAC International ; 79(1996) : 1107.

10. Brause, A.R., Poids lourds, M.W., Thomas, F.S., \& Page, SW. (1996). Détermination de la patuline dans le jus de pomme par chromatographie en phase liquide: étude collaborative. Journal of AOAC International; 79(2): 451- 455.

11. Matthew, M.M., Olga, I.P-Z., \& Randy, WW. (2005). Comprehensive review of patulin control methods in foods. Comprehensive Reviews in Food Science and Food Safety; 1(2005): 8-21.

12. ISO 8128-1. (1993). Apple juice, apple juice concentrates and drinks containing apple juice - Determination of patulin content - Part 1: Method using high-performance liquid chromatography.

13. CEAEQ (Centre d'Expertise en Analyse Environnementale du Québec). (2015). Protocole pour la validation d'une méthode d'analyse en chimie, DR-12-VMC, Québec, Ministère du Développement durable, de l'Environnement et de la Lutte contre les changements climatiques, 29 p.

14. Feinberg, M. (1995). Validation interne des méthodes d'analyse. Techniques de l'ingénieur, Paris, France, P224 : 1-23.

15. Institut National de Santé Publique du Québec. (2013). Comparaison des limites de détection déterminées par répétabilité et par reproductibilité. Rapport, $12 \mathrm{p}$.

16. Barreira, M., Alvito, P., \& Almeida, C. (2010). Occurrence of patulin in apple-based-foods in Portugal. Food Chemistry ; 121(3) : 653-658.

17. Blanchin, M-D. (2010). Validation des méthodes d'analyse. Journées Qualité et Chimie 2010 : Une démarche qualité au service de la chimie, Autrans - 14 octobre 2010, 40p.

18. Amani, N'G.G., Techi, F.A., \& Coulibaly, A. (2004). Propriétés physico-chimiques de l'amidon de gingembre (Zingiber officinale Roscoe) de Côte d'Ivoire. TROPICULTURA ; 22(2) : 77-83. 
19. Brackett, R.E., \& Marth E.H. (1979). Ascorbic acid and ascorbate cause disappearance of patulin from buffer solutions and apple juice. Journal of Food Protection ; 42(11) : 864-866.

20. EC (European Commission). (2002). Implementing Council Directive 96/23/EC concerning the performance of analytical methods and the interpretation of results. Official Journal of the European Communities; L221/8-L221/36.

21. USFA (United States Food and Drug Administration). (2004). Compliance policy guide. Compliance policy guidance for FDA staff. Sec. 510.150. Apple juice, apple juice concentrates, and apple juice products. Adulteration with patulin.

22. Gökmen, V., \& Acar, J. (1998). Incidence of patulin in apple juice concentrates produced in Turkey. Journal of Chromatography A; 815(1) : 99-102.

23. Alankar, S., \& Vipin. BG. (2011). Methods for the determination of limit of detection and limit of quantitation of the analytical methods. Chronicles of Young Scientists; 2(1) : 21-25.

24. Vassault, A., Hulin, A., Chapuzet, E., Arnaud, J., Giroud, C. \& les membres du sous-groupe 2 analytique de la SFBC. (2010). Vérification/validation des performances d'une méthode d'analyse. Annal Biologie Clinique ; 68 (1) : 247-294.

25. Aké, M., Eba, B., Malan, K.A., \& Atindehou, E. (2001). Sciences des Aliments 21(2):199-206 